\section{Northwest Atlantic}

Serial No. N1910

\section{Fisheries Organization}

SCIENTIFIC COUNCIL MEETING - JUNE_ 1991

Feeding Behaviour of the American Plaice (Hippoglossoides platessoides) on the Southern Grand Bank of Newfoundland

by

Javier Zamarro

Instituto de Investigaciones Marinas, Eduardo Cabello 6 Vigo, Spain

\title{
ABSTRACT
}

This study shows that the diet of American plaice on the Southern Grand Bank, at sizes between 40 and $55 \mathrm{~cm}$, is mainly A.dubius and brittle stars, the third prey in importance is M.vilingua.

To analyse feeding intensity during a daily and annual cycle, we used three different indices, the mean weight fullness index, the porcentage of empty stomachs and the daily ration.

The daily feeding intensity shows maxima related to the kind of prey eaten. A.dubius is consumed in larger amounts late in the day (18-24 hours), M.villosus and brittle stars are preyed upon more intengety'between 12 and 18 hours.

Maximum feeding activity is in April, with a summer period of relatively high values, followed by autumn and winter when feeding intensity is low.

The American plaice shows flexibility in its feeding behaviour, that allows it to consume, its prey in larger amounts when they are more accessible; this accessibility may be the cause of its daily and annual feeding cycle.

\section{INTRODUCTION}

The American plaice is widely distributed on both sides of the North Atlantic, from Iceiand and Southern Spizbergen to the British Isles in the East, and from Frobisher Bay and Baffin Island to Rhode Island in the western Atlantic (Scott, 1989). This species is commercially exploited species, and its most important fishery is on the Grand Bank of Newfounland, with catches reaching $94,000 \mathrm{mt}$ in 1967 (Brodie, 1990). 

Data processing

The weight of the stomach content was expressed as a fullnes index, obtained by expressing the content as a percentage of body weight. Using the size woight relation obtained in June and July, the weight fullnness index was calculated for all stomach content and for each prey.

We used three indeces to measure feeding activity, the mean weight fullnnes index (MWFI), the percentage of empty stomachs (PES), and the daily ration (DR).

The changes in feeding activity in a 24 hour cycle were analysed by grouping the samples into six hour intervals, using two hours before hauling as a reference time for the tow sampled. The MWFI and PES were calculated for each interval. The June and July samples were convined and grouped into four hour intervals for all calculations.

The monthly feeding activity was analysed with the means of the MWFI and PES obtained to group the samples for houres, geting a values of MWFI and PES representative of the diferent feeding intensities of the day for each month.

To analyse differences between PES obtained in the 24 hour and annual cycles, we used a Chi-square test with a significance level of 0.05 , and the MWFI was studied with a nonparametric analysis of variance of Kruskal Wallis (Siegel 1988); a significance level of 0.05 was used.

\section{Daily ration}

The daily ration was calculated using Elliot and Persson's model (1978), which assumes continuous fish feeding, with an exponential rate of evacuation $(R)$ which is independent of the fish size, amount of food or feeding frequency, and dependent on temperature $(T)$ and the kind of prey.

If samples are taken at $t$ hour intervals, the mean stomach content, expressed as a percentage of body woight (Si) within each interval i, is obtained lor a total ol m intervals jil a $24-$ hour period, the daily ratio (DR) can be calculated with the equation

$D R=(R t / I-\exp (-R t)) \sum S i(1-\exp (R t))=24 \mathrm{SR}$

where $\mathrm{S}=\sum \mathrm{Si} / \mathrm{m}$ 
The rate of evacuation ( $R$ ) is obtained from the expression:

$R=a \exp ($ bT) (E11iot 1972)

Durbin et al (1983) indicate that the parameter b is almost constant for different species and prey, with a mean value of 0,115 . Parameter a depends on the kind of prey considered; there are no estimates of a for American plaice. Stomach contents were classified into fish and non-fish prey, and a value of a obtained for each group.

Frum the stomach contents of prey other than fish, mainly Brittle stars, which have a high proportion of indigestible material, the parameter a was calculated from the time necesary to evacuate half the stomach content of oldia sapotilla (Bivalvia) obtained by MacDonald and waiwood (1982) in H. platessoides, Gadus morhua and Macrozoarces americanus. The value obtained was $\underline{\mathrm{a}}=0.198$.

For fish content, mainly A. dubius, the value a $=0.0143$ obtained by Dwyer et al'(1987), for Teragra chalcogramma (Gadidae), feeding on juveniles of the same species was used. This value was also used by Yang (1988) for calculating the daily consunption in Reinhardtius hippoglossoides.

The temperature (T) was $2.5 \mathrm{c}$, obtained from the mean bottom temperature in the Southern Grand Bank in Spring and Summer 1972-86 (Borovkov 1988).

\section{RESULTS}

The monthly MWFI for each prey is represented in figure 1 , in this figure we can see a wide variety of prey but only two of them are important to consider in the annual cycle (Table 2). These are the Northern Sand Lance (Ammodytes dubius) and the brittle stars. Capelin (Mallotus villosus) is the third prey in importance although only present in important quantities in April.

The presence frequency of each prey is showed in figure 2, A.dubius and the britle stars continue being the more important prey.

The kind of proy consumed varies seasonaly as show the figures 1 and 2 , A.dubius is consumed in larger amounts and is 
present more frequetly in the stomachs of spring and summer, and the brittle stars are more important during winter feeding, although they are also consumed during the rest of the year.

\section{Daily feeding cycle}

In order to analyse the changes in feeding activity in a 24 hour cycle, we show in figures 3,4 and 5 the MWFI at different times for the months with more foering activity (April, June-July and August). The MWFI are significantly different in all nonths, which indicates that during the day Feeding activity in these months is not the same; maximun values are obtained between 12-18 hours in April, 20-24 hours in June-July and 18-24 hours in August.

The PES at different times for the same months are significantly difforents (Fig. 6), which indicates also that the feeding activity is not the same during the 24 hours. The distribution of these values show an opposite tendency to the MWFI; the lower percentages of empty stomachs coincide with maximum values of MWFI.

The MWFI at different times for the more important prey (Fig. 3,4 and 5) show behave diferently. A.dubius is always found in larger amounts in the last hours of the day, M.villosus in April show the maximum values between 12 and 18 hours, and the brittle stars present in June-July the maximum between 12 and 16 hours.

'l'he more important prey are not present during all months in the depth range sampled. To avoid the effect that depth could have on the results, we reduced the analysis of each proy to the range of depth found each month. The values of the MWFI for capelin in April in depths between 63 and 120 fathoms are represented in figure 7 . These values are significantly different, with a maximum value between 12 and 18 hours.

A.dubius in April was present in the samples made between 29 and 88 fathoms, in July in all depths sampled (69-89 f) and in August between 28 and 37 fathoms. The MWFI of A.dubius for these depths (Fig. 8) showed significant differences from the maximum values before midnight, between 18 and 24 hours in April 
and August and between 20 and 24 hours in June-July. The percentage of stomachs with A.dubius shows the maximum values at the same hours (Table 3 )

Brittle stars in June-July were found at alI depths sampled $(69-89$ f). The values (fig. 7) showed significant differences with a larger value between 12 and 16 hours, although the trend is not so marked as in fish. The percentage of stomachs with brittle stars and MWFI in February, Apri1, June, July, November and Deccember show the maximum values between 12 and 18 hours (Table 4).

To test if the differences observed in the MWFI are linked to the amount of each prey in individual predators, we analysed the MWFI for each prey excluding the empty stomachs and the content of other prey. The result is that A.dubius is present in April, June-July and rugust with significant differences between the MWFI at different times of the day (Fig.9), the maximum values vere found at lust tine of the clay. Iho changes in the MWFI of $\Lambda$ :dubius (all stomachs convined fig. $3,4,5)$ show the same trend as the variations of the MWFI based only on individuals with this prey.

In the case of M.villosus in April, and the brittle stars in June-July (Fig 10), the differences between the MWFI at different times are not significant, and the changes observed (all stomachs combined) are due to the number of individuals with this prey (table 5).

The daily fecding cycle according to these resuits doos not have the same intensity during throughout the day, and is related to the lidnd of joul witur.

\section{Annual fecding cycle}

The monthly MWFI is shown in figure 11, The maxinum value is 1.193 in April followed by intermediate valuss in simmer and lower values in fall and winter; the minimum is; $0.05 \%$ in Jantary. The feeding intensity in relation to the PES (Fig.12) shows two differents periods, with relatively low values (40z-53\%) from April to september, and an autumn-winter poriod with values between 778 and 938 of empty stomachs, indicating a period of low 
feeding activity. The maximum PES coincides in January with the minimum of MWFI.

The third indicator of the changes in feeding activity is the monthly DR (Fig. 13). Its changes are lees pronounced than the MWEI but with the same trend, the maximum is in April with a consumption of 0.648 of the body weight and the minimun in January with 0.048 .

These changes in the annual feeding activity of American plaice, show an cycle with a maximum in spring followed by a period in summer when the activity is maintained at relatively high values; feeding is low during autumn and winter, especially in January when there is almost no feeding activity.

\section{DISCUSSION}

The results obtained show that the Anerican plaice on the Tail of the Grand Bank in the size range analysed $(40-55 \mathrm{~cm})$, can feed on a wide variety of prey, fish (A. dubius and M.villosus) being the more important followed by brittle stars. This feeding based on fish was also found by pitt (1973) in his analysis of stomachs contents, and by Groot (1969) who studied the proportion of the different parts of the digestive system.

To compare the values of daily ration obtained with the Elliot and Person's model (1978) we approximated the food caloric content. For this ve used a caloric content of $1.7 \mathrm{Kcal} / \mathrm{gr}$ for fish, as estimated by Pitt (1973) in A.dubius, and a value of 0.4 $\mathrm{Kcal} / \mathrm{gr}$ for the rest of the prey wich is the mean value for brittle stars of Brawn (1968). The caloric content obtained is show in figure 14, and is 368 lower than the needs stimated by Mackinon (1972). It should be noted that the mean size of our samples is about ten centimetres larger than the fish studied by Mackinon, and smaller fish consume proportionately more energy. The lack of sampling in March and May, months of high feeding activity, may explain this difference, if we take into account that 288 of the annual food caloric content is obtained in April, and that unpublished data show that feeding in March in the ivortheast of the Grand Bank is on fish with a level laryer than obtained by us in April. Sampling in March and May in this area 
may be necessary to obtain a more precise evaluation of the daily ration.

Daily feeding rhythm

The results show that the American plaice analysed here do

not feed with the same intensity throughout the day. The maximun values in summer are at the last time of the day, and in April between 12 and 18 houres, in the begining this could have relation with a larger activity at dusk that is before in April than summer, it being associated the feeding behaviour with the dayligth intensity; important factor for Grott(1969) that analysing the development of the sensorial organs conclude that the American plaice head for its preys guided for the sight. But when we analyse the behaviour in relation to its more important preys, we can observe that is different for anch one, it being the case more pronounced of A.dubius that in all the months studied is consumed in larger ammounts at last time of the day. Scott (1988) says that A.dubius remains buried during the day time, as protection against predator going out in the evening to feed on plankton. Our results show that this is the period when American plaice feeds most actively on this species.

Capelin presents a pattern of diel vertical migrations (Bailey et al. 1977, Kovalyov et al 1973, Dragesund et al 1973). During the day it is distributed near the bottom layers in rather dense schools and at night the schools rapidly move upward into the near surface layers, and dispersed. These vertical migrations of capeitin are in relation to their feeding activity (Vesin et al. 1981), which is more intensive during the migrations (6-10 hours and 16-22 hours) and less intensive during the period on the bottom $(10-16 \mathrm{~h})$. Our results show that the Anerican plaice feeds on capelin more intensively between 12 and 18 houres, when this prey is on the bottom in dense schools and does not feed, resulting more available for the American plaice. Brittle stars show in all the months analysed maximum feeding activity between 12 and 18 hours, we do not know a behaviour of this prey to explain this maximum, but the higher intensity of Iigth may do more availables the brittle stars. 
The American plaice studied here has a teeding behaviour with time flexibility, what allows it to consume its preys in ..

larger amounts when they are more accessible, being the daily

cycle of feeding intensity in relation to the kind of prey that is eating.

Annual feeding rhythm

The indices used to analyse the annual. feeding intensity show a heavier activity in spring followed by a period of relatively high cosumption in summer and a weak activity in autumn, reaching the minimun feeding in winter when there is almost no activity. This feeding behaviour is consistent with the energy storage obtained by Mackinon (1972) in the American plaice from St. Margaret Bay. According to Mackinon the American plaice stores energy in summer that will be used in metabolism and gonad maturation in winter. The observations of larger feeding intensity in April coincide with the lower values of somatic index and caloric content of the body outained by Mackinon (1972). The disminution in autumn of the feeding activity coincide with the maximun values in the somatic index and caloric content obtained by Mackinon for September.

The seasonal changes of temperature could have an effect on activity of American plaice, but its variations do not show the same trend as feeding intensity (Trites 1982 and Borovkov 1988), These changes in temperature are also low if we take into account that the American plaice is a species adapted to cold waters and changes between 1 and 6 degrees do not produce important changes in metabolic activity (Mackinon 1973). Temperature as metabolic reyulator wo not seens to we the determinant factor of the annual feeding activity.

For Mackinon (1972) a cycle of energy storage for its
posterior utilization is an adaptation to an irregular
disponibility of food. The highest feeding intensity of
American plaice was associated with a greater consumption of
A.dubius, the catch per successful set of A.dubius in the bottom
trawl surveys carried out by the A.T Cameron, $1959-80$ (winter
$1983)$ shows a period of high availability between April and


October, and another of low availability between November and March. These periods coincide with the greatest and lowest or null consumption of this prey obtained by Pitt (1973) and us in this study, and it may indicate that there are also a period of high and low availability of this prey for the American plaice. Our results show the American plaice as a species with a capacity to feed on a wide variety of preys, actuating on them with time flexibility which allows catch them when they are more accessible. This accessibility may be the cause of the daily and annual feeding cycle obtained.

\section{BIBLIOGRAPHY}

BAILEY,J.R.F.,K.W.ABLE, AND W.C.LEGGETT, 1977 . Seasonal and vertical distribution and growth of juvenil and adult. Capelin (Mallotus villosus) in the St. Lawrence Estuary and western Gulf of st. Isawrence. J.Fish.Res. Board.Can. 34:2030-2040.

BOROVKOV.V.A., and I.I.TEVS. 1988. Temperature of bottom waters over the Newfoundland Shelf in spring-summer 1972-1986. NAFO. SCR. DOC. 88/97. $16 \mathrm{pg}$.

BRAWN, V.M., D.L.PEER, and R.J.BENTLEY. 1968. Caloric content of the standing crop of benthic invertebrates of St. Margaret's Bay, Nova Scotia. J. Fish. Res. Board Can. 25: 1803-1811.

BRODIE,W.R., W.R. BOWERING and J.W. BAIRD. 1990. An assessment of the American plaice stock in division 3LNO. NAFO SCR DOC. 90/80, $41 \mathrm{pP}$

DRAGESUND, O., and T. MONSTAD. 1973. Observations on capelin, Mallotus villosus, in Newfoundland waters. Int. Comm. Northwest Atl. Fish. Redbook, Part III:127-136

DE GROOT,S.T. 1969.

Digestive system and sensorial factors in relation to feeding behaviour of flatfish (Pleuronectiformes). J. Cons. Perma. Int. Explor. Mer. 32: 385-395.

DURBIN,E.G., A.G.DURBIN., R.W.LANGTON, and R.E.BOWMAN. 1983. Stomach contents of silver hake, Merluccius biliniaris, and Atlantic cod, Gadus morhua, and estimation of their daily rations. Fish. bull. u.s. 81: 437-454

DWYER,D.A., K.M.BAILEY, and P.A.LIVINGSTON. 1987. Feeding habits and daily ration of walley pollock (Teragra chalcogramma) in the easter Bearing sea, with special reference to canibalism. Can. J. Aquat. Sci. 44; 19721984 . 
ELLIOT, J.M. 1972

Rates of evacuation of brown trout, salmo trutta.

L.Freshw. Biol. 2:1-18

ELLIOTT, J.M. and L. PERSSON. 1978

The estimation of daily rates of food consumption for fish. Journal of Animal Ecology. 47:977-991

HUNTER, J.R 1985

Preservation of Norther Anchovy in formaldehyde solution. In An egg production method for estimating spawning biomass of pelagic fish: Aplication to the Northern Anchovy, Engraulis mordax. NOAA Technical Report NMFS $36: 63-65$

KOVALYOV,S.M., and B.D.KUDRIN. 1973.

Soviet investigations on capelin in the Northwest Atlantic in 1971 and 1972. Int. Coomm. Nothwest Atl.Fish. Redbook, Part III:121-126

MACDONALD.J., and K.G. WAIWOOD. 1982.

Rates of digestion of different prey in Atlantic cod (Gadus morhua), ocean pout (Macrozoarces americanus), Winter Flounder (Pseudopleuronectes americanus), and American plaice (Hippoglossoides platessoides). Can.J.Fish.Aquat.Sci. 39:651-659

MACKINNON, J.C. 1972 .

Summer storage of energy and its use for winter metabolism and gonad maturation in American plaice (Hippoglossoides platessoides). J.F'ish.kes.board Can. 29:174 9-1759

MACKINON, J.C. 1973

Metabolism and its relationship with growth rate of American plaice, Hippoglossoides platessoides, J. exp. mar. Biol. Ecol, 11:297-310

MINET,J.P. 1974

Donnés sur la biologie de la plie americaine Hippoglossoides platessoides des bancs méridionaux de Terre Neuve et du plateau du Cap Breton. Revue des travaux de l'Institut des Peches Maritimes. 38: 347-429.

PITT,T.K. 1973.

Food of American plaice (Hippoglossoides platessoides) from the Grand Bank, Newfoundland. J.Fish.Res,board Can. 30: 1261-1273

PITT,T.K. 1975

Sexual maturity and spawning of the American plaice, Hippoglossoides platessoides (Fabricius), from Newfoundland and Grand Bank areas. J.Fish. Res.Bd.Canada.23:651-672

POWLES, P.M. 1965.

Life history and ecology of American plaice (Hippoglossoides platessoides) in the Magdalen shallows. J.Fish.Res.board Can. 22:565-598

SIEGEL.S and N.J. CASTELLAN. 1988.

Nonparametric statistics for the behavioral sciences. MC Graw-Hill Book Company. 399pp

SCOTT,J.S. 1973

Variation in the food of American plaice (Hippoglossoides platessoides) with fish lenght and locality in the scotian Shelf and Gulf of St. Lawrence. Fish.Mar.Ser.Der.Tech.Rep. 411:14pg.

SCOTT,J. and S. SCOTT. 1988.

Atlantic fishes of Canada. Can.Bull.Fish.Aquat.Sci. 219. $731 \mathrm{pg}$. 
TRITES,R.พ. 1992 .

Overview of oceanographic conditions in NAFO subareas 2,3 and 4 during the 1970-1979 decade. NAFO Sci. Coun. Studies, $5: 51-78$

VESIN,J.P.,W.C.LEGGETT, and K.W.ABLE. 1981

Feeding ecology of capelin (Mallotus villosus) in the estuary and western Gulf of St. Lawrence and its multispecies implications. Can.J.Fish. Aquat. Sci. 38:257-267

WIN'ERS, G.H. 1983.

Analysis of the biological and demographic parameters of Northern Sand Lance, Ammodytes dubius, from the Newfoundland Grand Bank. Can.J.Fish. Aquat.Sci.40:409-419

YANG,M.S. and P.A.LIVINGSTON. 1978.

Food habits and daily ration of Greenland halibut, Reinhardtius hippoglossoides, in the Easter Bearing sea. Fish. BuIl. 86:675-690

Table 1. Characteristics of the sampling $(\mathrm{N}=$ number of stomachs analysed, $\mathrm{MS}=$ Mean size, $\mathrm{RS}=$ Range of sizes, $\operatorname{Max}=$ Maximum depth, Min= minimum depth, $M D=$ Mean depth).

$\begin{array}{lrccccc}\text { Month } & \text { N } & \text { M13 } & \text { RS } & \text { Max } & \text { Win } & \text { MD } \\ \text { January } & 513 & 44.84 & 40-55 & 179 & 32 & 72.4 \\ \text { February } & 403 & 44.8 & 40-55 & 180 & 41 & 70.8 \\ \text { March } & 0 & - & - & - & - & - \\ \text { April } & 477 & 45.7 & 40-55 & 120 & 29 & 66 \\ \text { May } & 0 & - & - & - & - & - \\ \text { June } & 393 & 46.7 & 40-55 & 88 & 70 & 76.3 \\ \text { July } & 1790 & 46.0 & 40-55 & 89 & 69 & 73 \\ \text { August } & 929 & 45.6 & 40-55 & 78 & 28 & 32.8 \\ \text { September } & 958 & - & 40-55 & 99 & 37 & 69 \\ \text { October } & 448 & 46.3 & 40-55 & 37 & 32 & 33 \\ \text { November } & 660 & 47.3 & 40-55 & 105 & 30 & 55.8 \\ \text { Deccember } & 773 & 45.8 & 40-55 & 155 & 33 & 67.2\end{array}$

Table 2 Annual stomach content (Sum of the monthly MWFI)

$\begin{array}{ll}\text { A.dubius } & 3.10 \\ \text { M. villosus } & 0.8 \\ \text { Other fishes } & 0.14 \\ \text { Brittle stars } & 1.24 \\ \text { Sea urchins } & 0.05\end{array}$

Mollusca 0.11

Crus.dec. 0.01

small crus. 0.01

polychaeta 0.01 
Table 3 Percentage of stomachs with A.dubius (8), number of stomach analysed (N), and 958 confidence interval (95\%) in the samples of April, June-Jly and August.

$\begin{array}{lcrcr} & \text { Time } & \mathrm{N} & 8 & 958 \\ \text { Apri1 } & 0-6 & 46 & 45.7 & 14.6 \\ & 6-12 & 66 & 34.9 & 11.7 \\ & 12-18 & 171 & 35.7 & 7.3 \\ & 18-24 & 92 & 60 & 10.2 \\ \text { June } & 0-4 & 328 & 16 & \\ \text { July } & 4-8 & 417 & 11 & 3.1 \\ & 8-12 & 383 & 18 & 4 \\ & 12-16 & 405 & 5 & 2.2 \\ & 16-20 & 402 & 13 & 3.4 \\ & 20-24 & 248 & 25 & 5.5 \\ \text { August } & 0-6 & 161 & 32.9 & 7.4 \\ & 6-12 & 205 & 25.9 & 6.1 \\ & 12-18 & 260 & 36.9 & 6 \\ & 18-24 & 216 & 42.1 & 6.7\end{array}$

Table 4 percentage of stomachs with brittle stars ( 8 ), number of stomachs analysed (N), 958 of confidence interval (95\%) and MWFI of brittle stars at different times.

$\begin{array}{lcrrrr}\text { Month } & \text { time } & N & 8 & 958 & \text { MWFI } \\ \text { February } & 0-6 & 73 & 9.6 & 6.9 & 0.04 \\ & 6-12 & 138 & 17.4 & 6.5 & 0.09 \\ & 12-18 & 111 & 29.7 & 8.7 & 0.15 \\ & 18-24 & 81 & 17.3 & 8.4 & 0.10\end{array}$

\begin{tabular}{lccccc} 
April & $0-6$ & 72 & 4.2 & 4.7 & 0.03 \\
& $6-12$ & 88 & 16 & 7.8 & 0.09 \\
& $12-18$ & 201 & 17 & 5.3 & 0.12 \\
& $18-24$ & 116 & 14 & 6.4 & 0.06 \\
June & & & & & \\
July & $0-4$ & 328 & 17 & 4.2 & 0.12 \\
& $4-8$ & 417 & 29 & 4.4 & 0.16 \\
& $8-12$ & 383 & 20 & 4.1 & 0.11 \\
& $12-16$ & 405 & 47 & 5 & 0.26 \\
& $16-20$ & 402 & 33 & 4.7 & 0.18 \\
& $20-24$ & 248 & 35 & 6.1 & 0.21 \\
\multirow{4}{*}{ November } & & & & & \\
& $0-6$ & 107 & 0.9 & 1.8 & 0.01 \\
& $6-12$ & 210 & 7.6 & 3.6 & 0.08 \\
& $12-18$ & 202 & 18.3 & 5.4 & 0.21 \\
& $18-24$ & 141 & 6.2 & 4.9 & 0.08 \\
\multirow{5}{*}{ Deccember } & & & & & \\
& $0-6$ & 234 & 2.1 & 1.9 & 0.01 \\
& $6-12$ & 198 & 13.6 & 5 & 0.09 \\
& $12-18$ & 159 & 24.8 & 7.3 & 0.33 \\
& $18-24$ & 182 & 18.2 & 6 & 0.13
\end{tabular}

Table 5 Percentage of stomachs with Mallotus villosus (o), 958 of confidence interval (95\%) and number of stomachs analysed (N) in April for depths between 63 and $120 \mathrm{f}$

\begin{tabular}{crrr} 
Time & N & \multicolumn{1}{c}{8} & \multicolumn{1}{c}{958} \\
$0-6$ & 26 & 7.7 & 10.5 \\
$6-12$ & 51 & 9.8 & 8.3 \\
$12-18$ & 182 & 36.8 & 7.2 \\
$18-24$ & 48 & 18.8 & 11.3
\end{tabular}



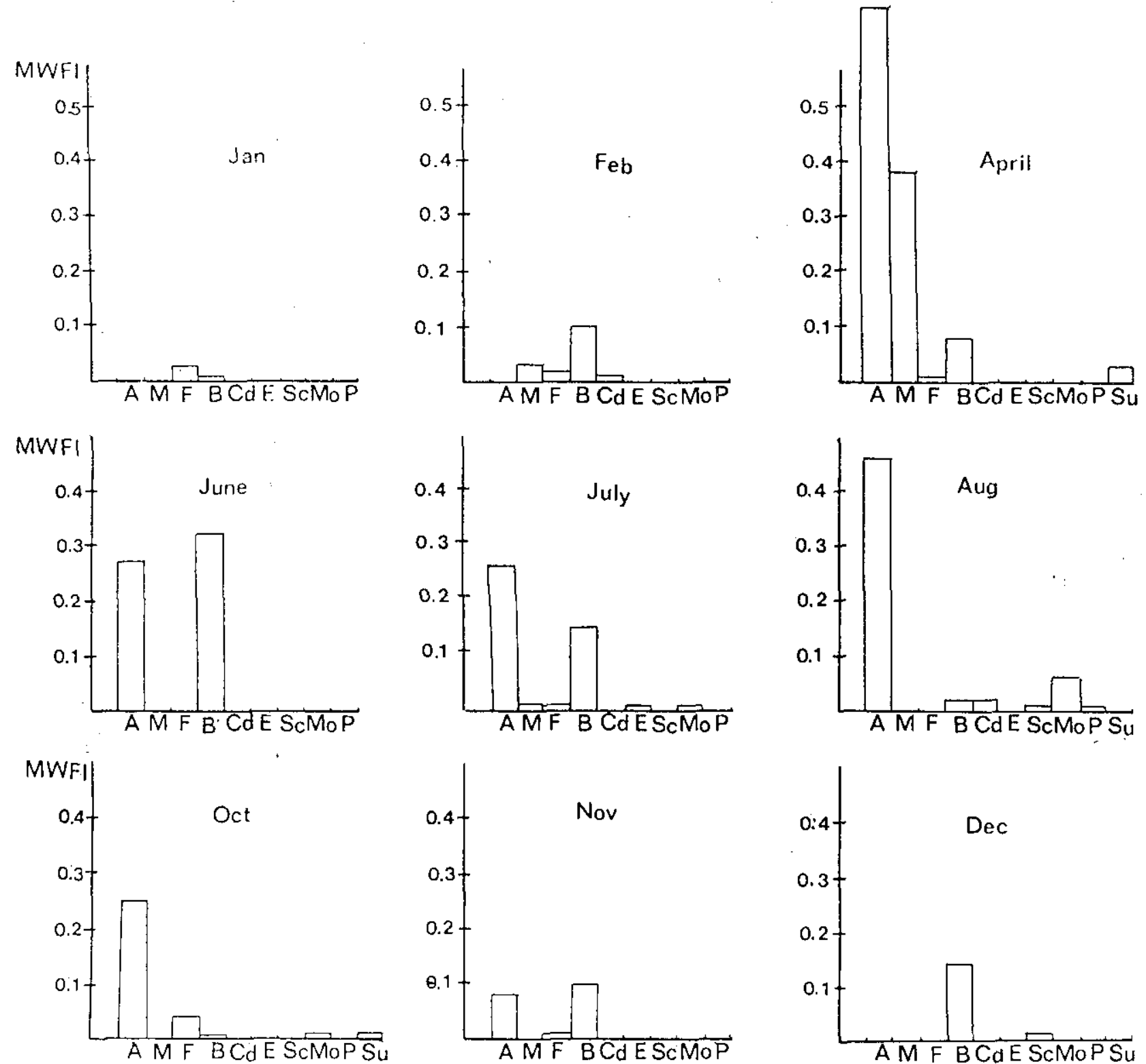

Figure 1. Monthly mean weight fullness index (MWFI) of American plaice for each prey on the southern Grand Bank. ( $A=A$.dubius,

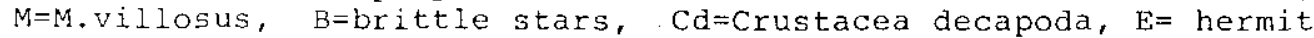
crabs, $\mathrm{SC}=$ Small crustacea, $\mathrm{Mo}=$ mollusca. $\mathrm{P}=$ Dolvchaeta sil= sna 

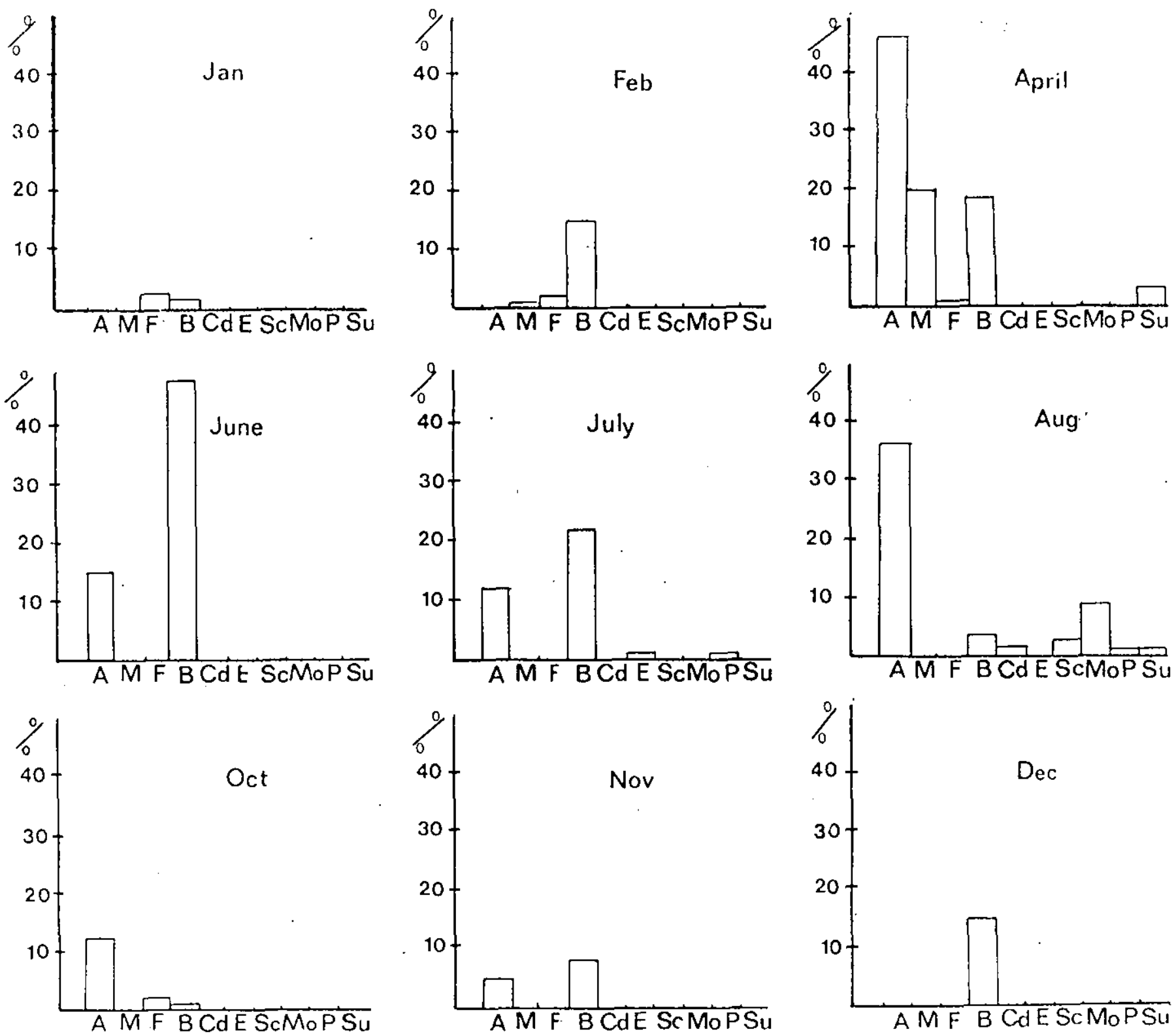

Figure 2. Monthly frequency of presence of each prey in the stomachs of American plaice on the Southern Grand Bank.

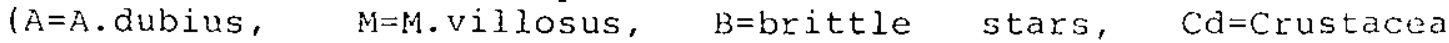
decapoda, $\mathrm{E}=$ hermit crabs, $\mathrm{SC}=$ Small crustacea, $\mathrm{Mo}=$ mollusca, $\mathrm{P}=$ poliqueta, su= sea urchin). 


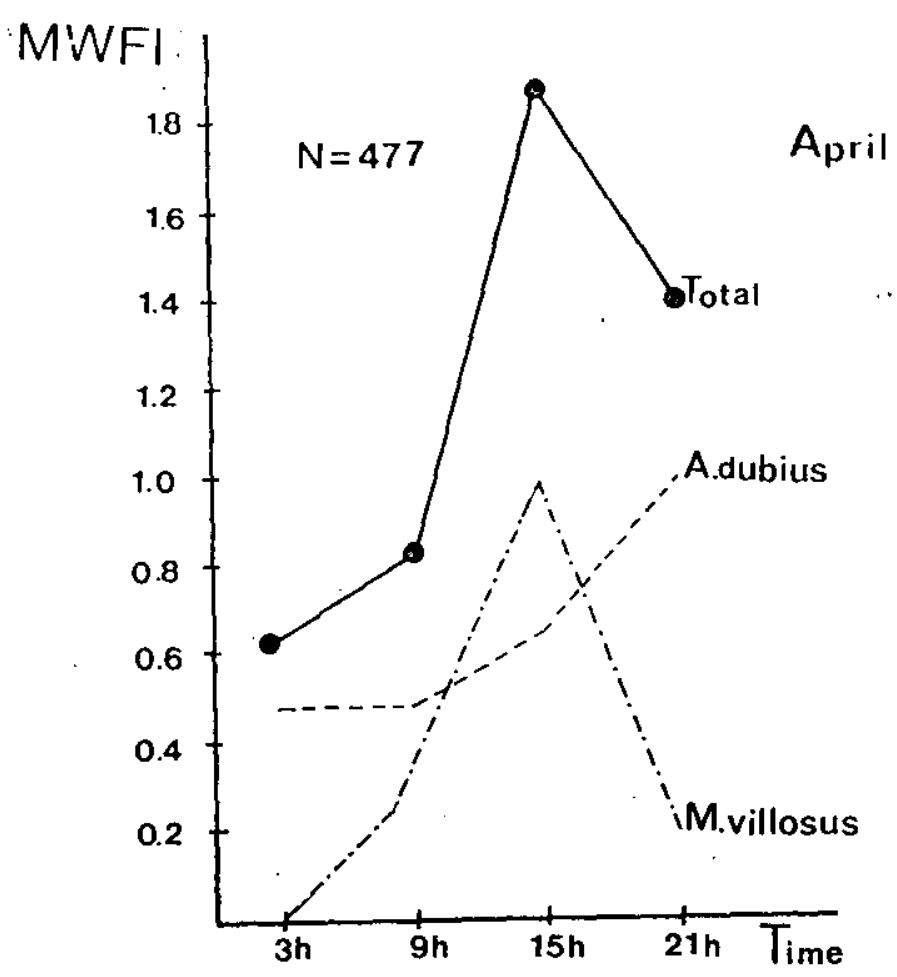

Figure 3. Mean weight fullness index (MWFI) of April, at diferent times, in the total of the stomach contents (TOTAL) and the partial MWFI corresponding to the more important prey (A.dubius and M.viliosus).

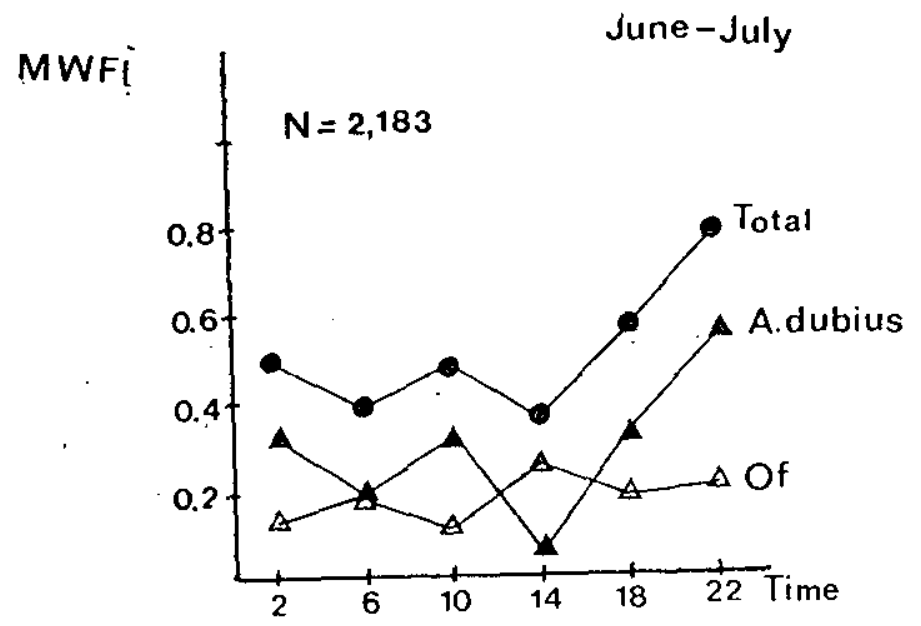

Figure 4. Mean weight fullness index (MWFI) in June-July, at different times, for the total of the stomach content (TOTAL) and the partial MFI corresponding to the more important prey (A.dubius and brittle stars). 


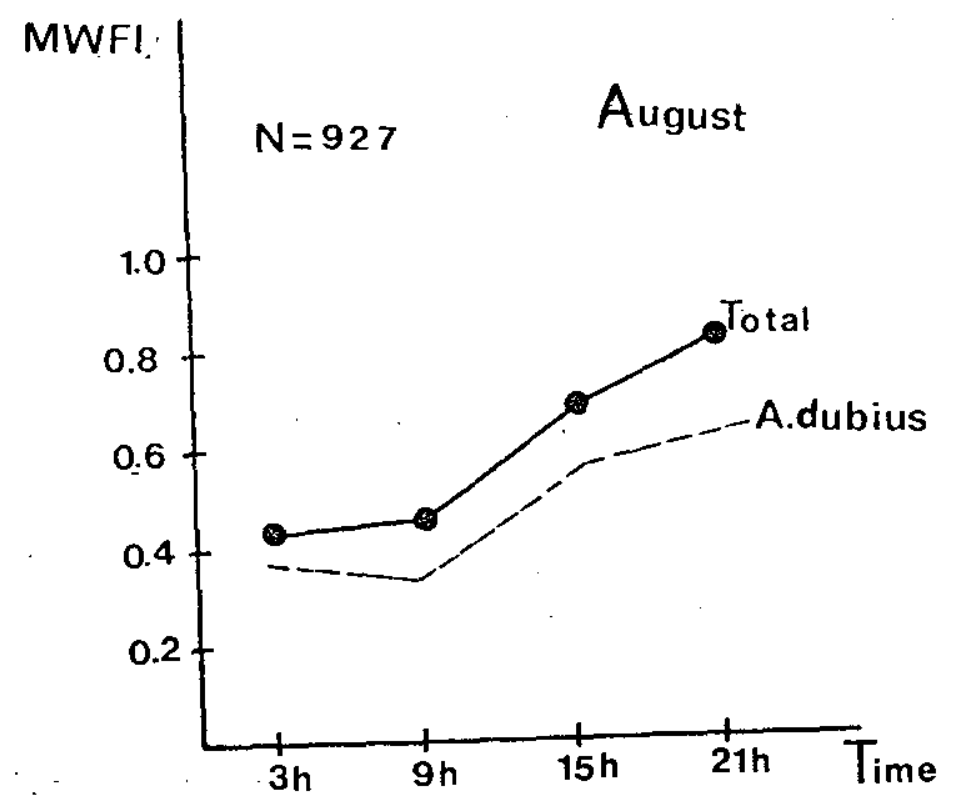

Figure 5. Mean weight fullness index (MWFI) in August, at diferent times, for the total of the stomach contents (TOTAL) and for A.dubius. 

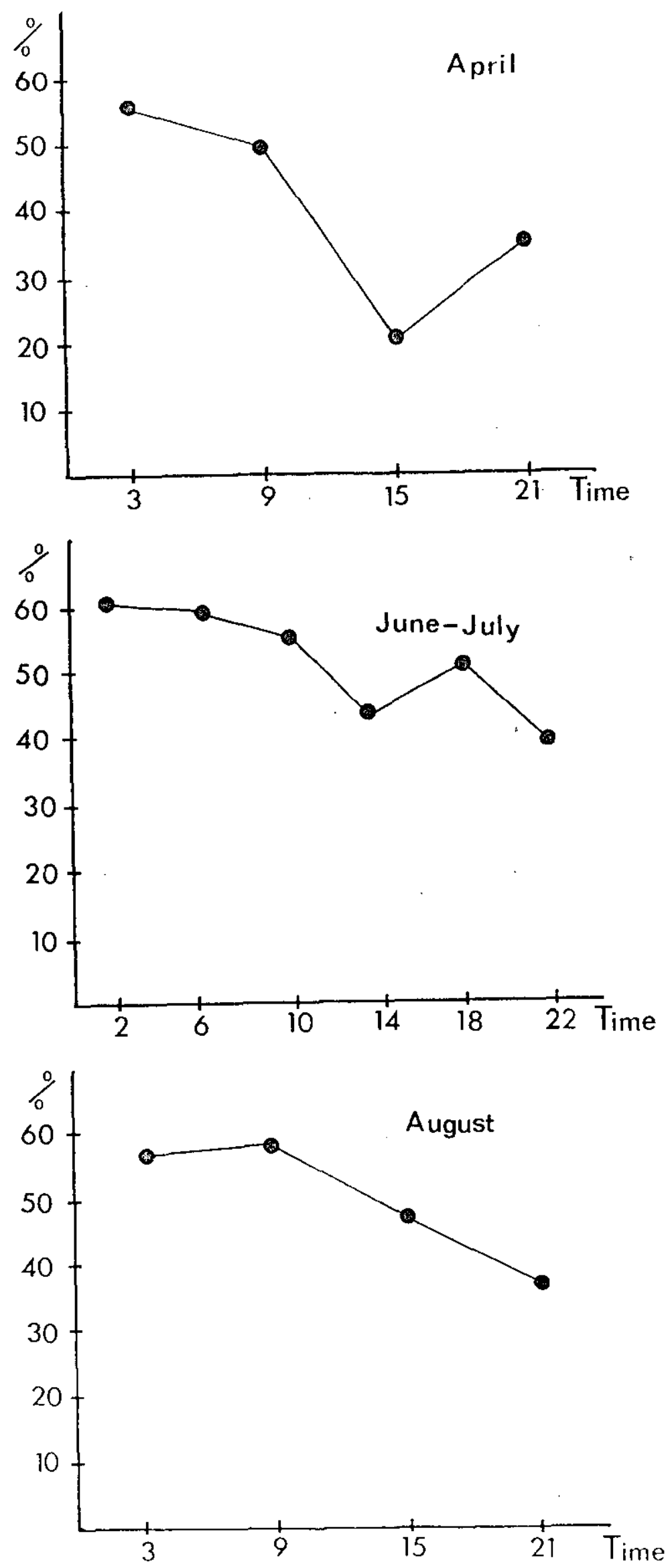

Figure 6. Percentage of empty stomachs, at different times, in April, June-July and August. 

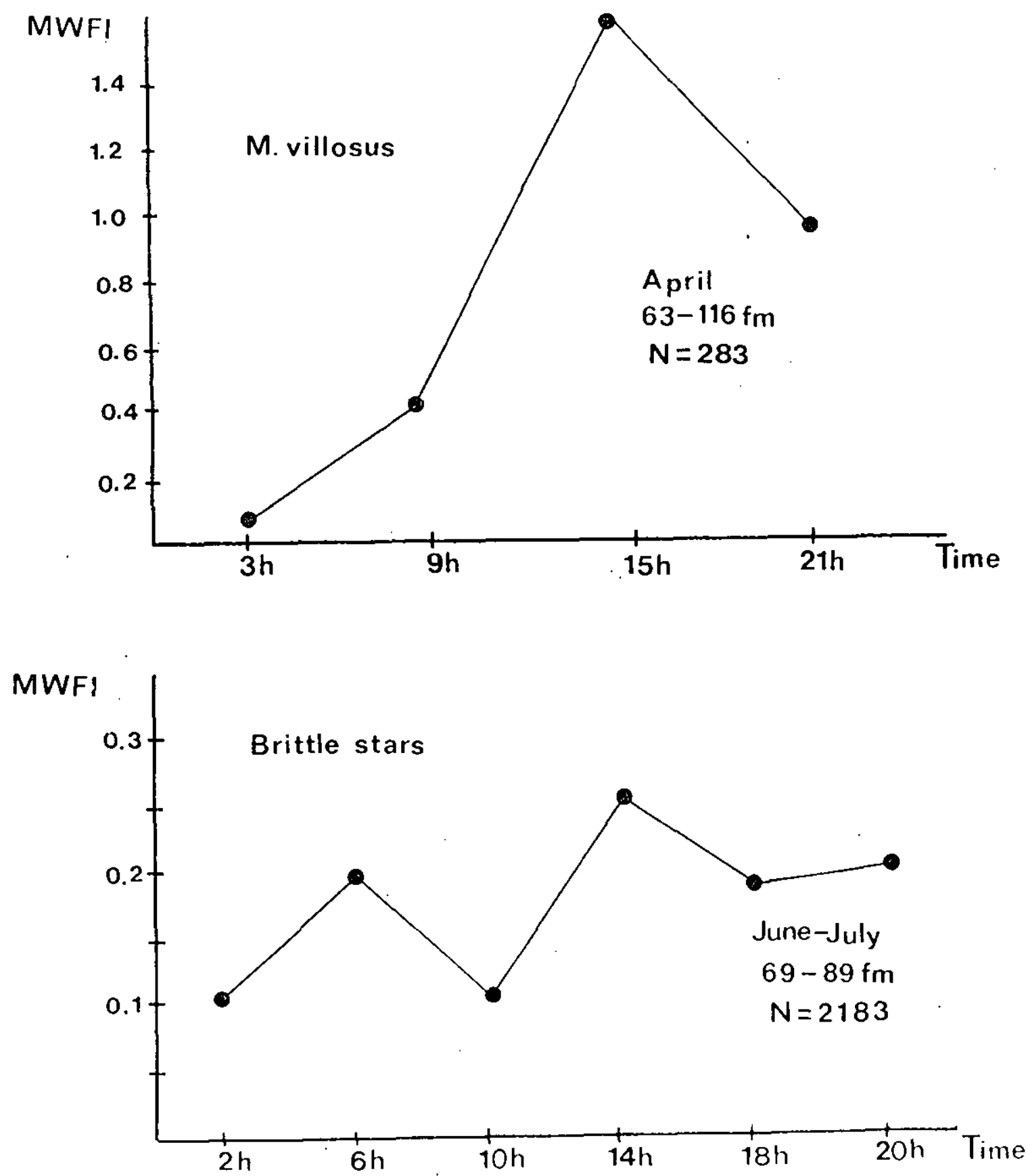

Figure 7. Mean weight fullness index (MWFI) of M.villosus and brittle stars in April and June-July, at different times, only for the range of depth where they were found. 

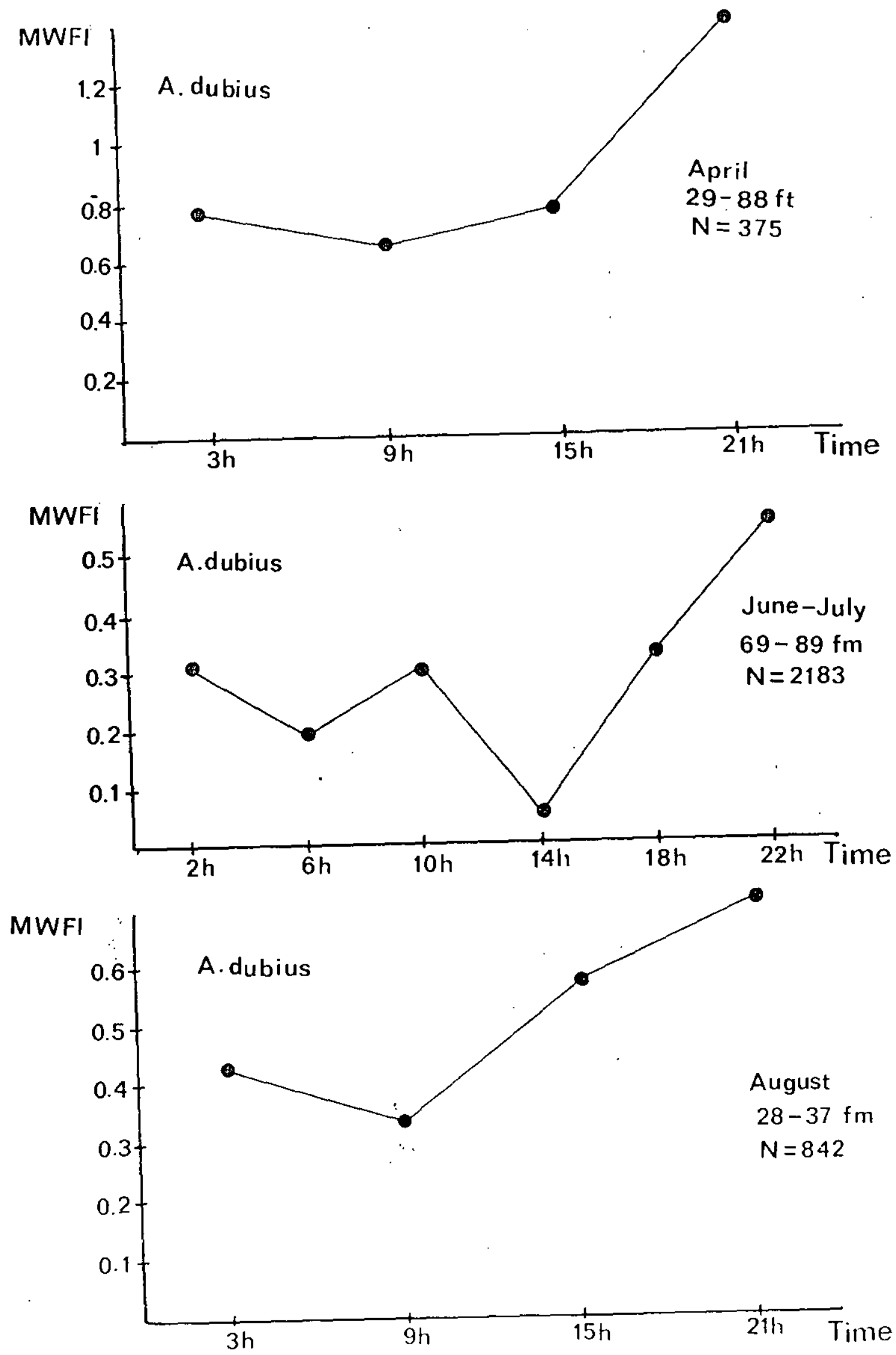

Figure 8. Mean weight fullness index (Mrifl) of A.dubius, at diferent times, in April, June-July and August, for the range of depths where they were found. 

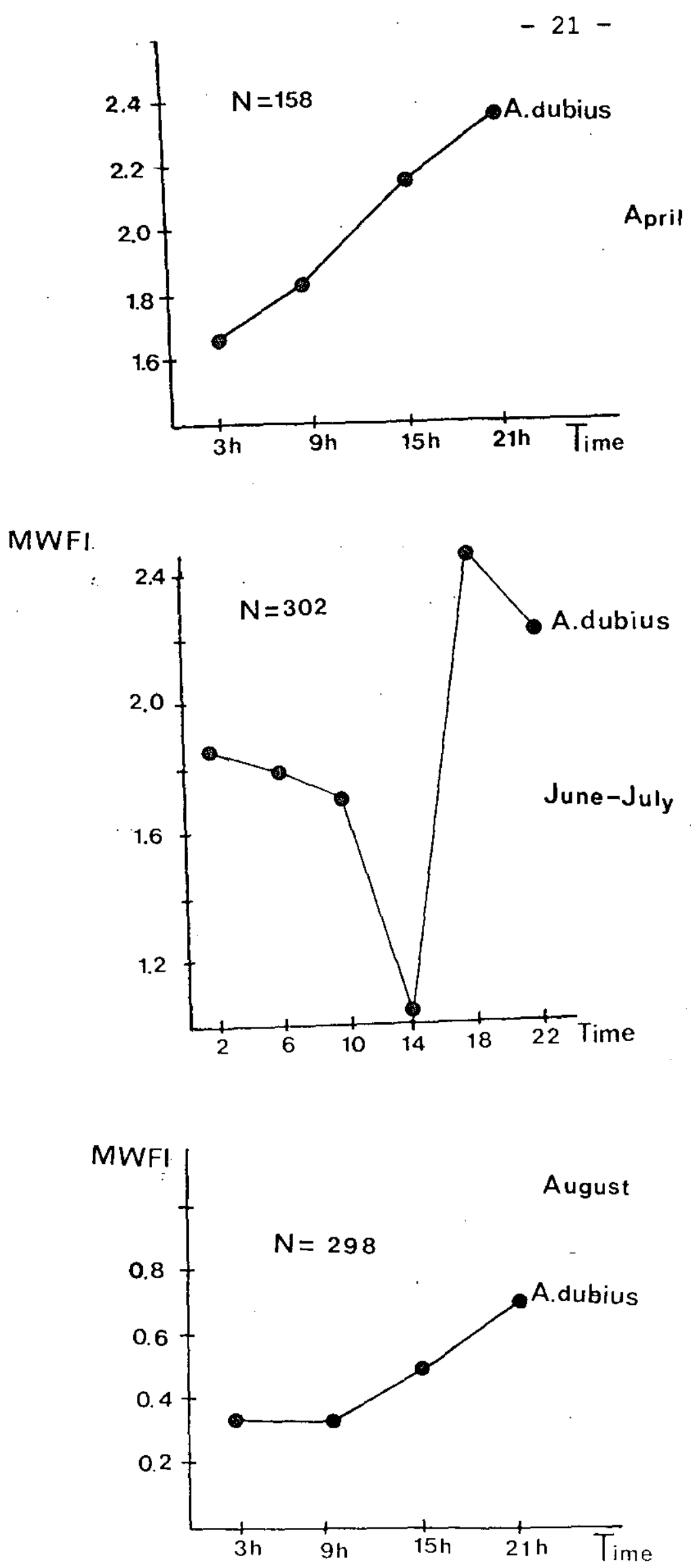

Figure 9. Mean weight fullness index (MWFI) of A.dubius in April, June-July and August at different times for the individuals with this kind of prey in the stomach content (excluiding the empty stomachis and other kinds of preyl. 


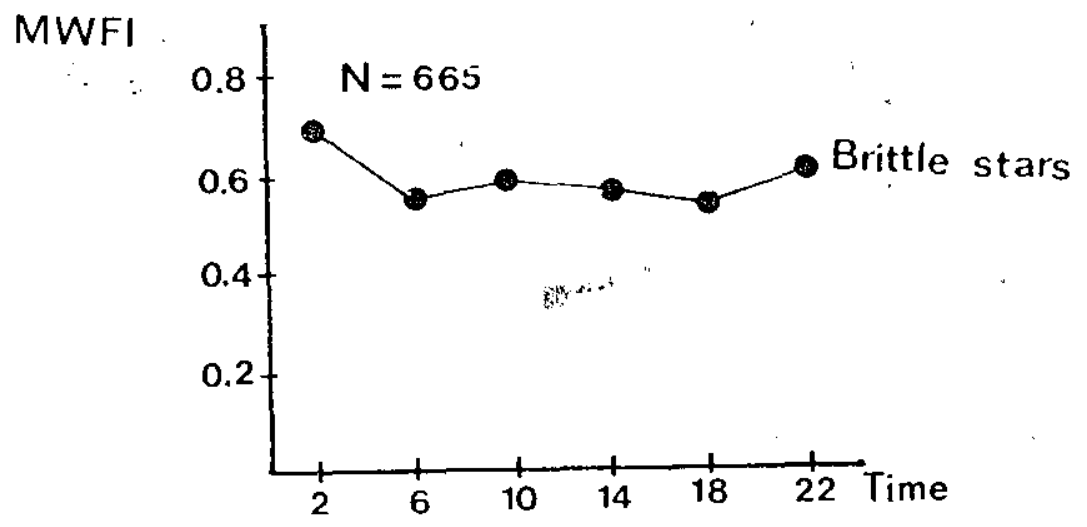

Figure 10. Mean weight fullness index (MWFI) of Brittle stars, at different times, in June-July for the individuals with this kind of prey (excluiding the empty stomachs and other kind of prey).

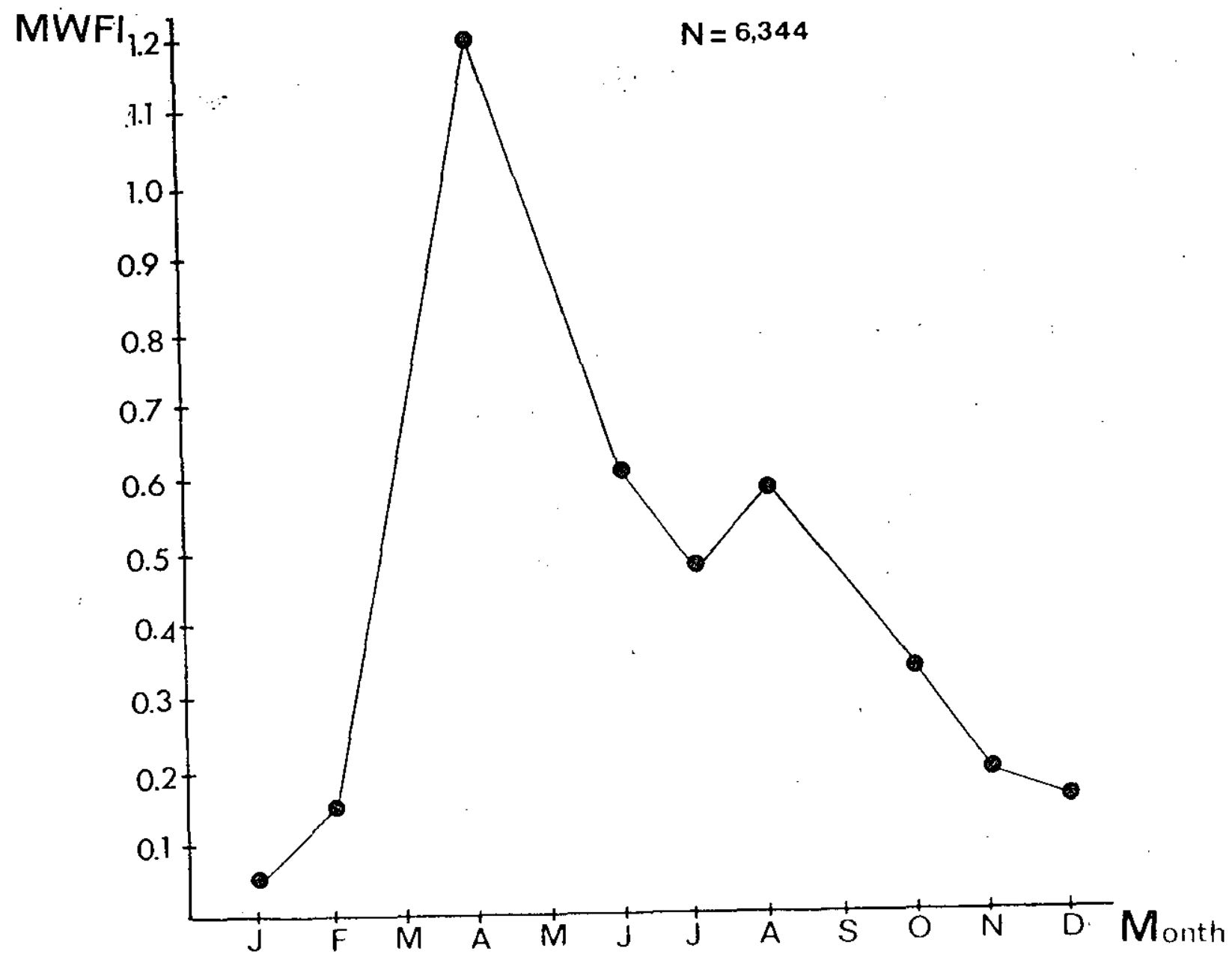

Figure 11. Monthly mean weight fullness index (Mwil) of American plaice on the Southern Grand Bank. 


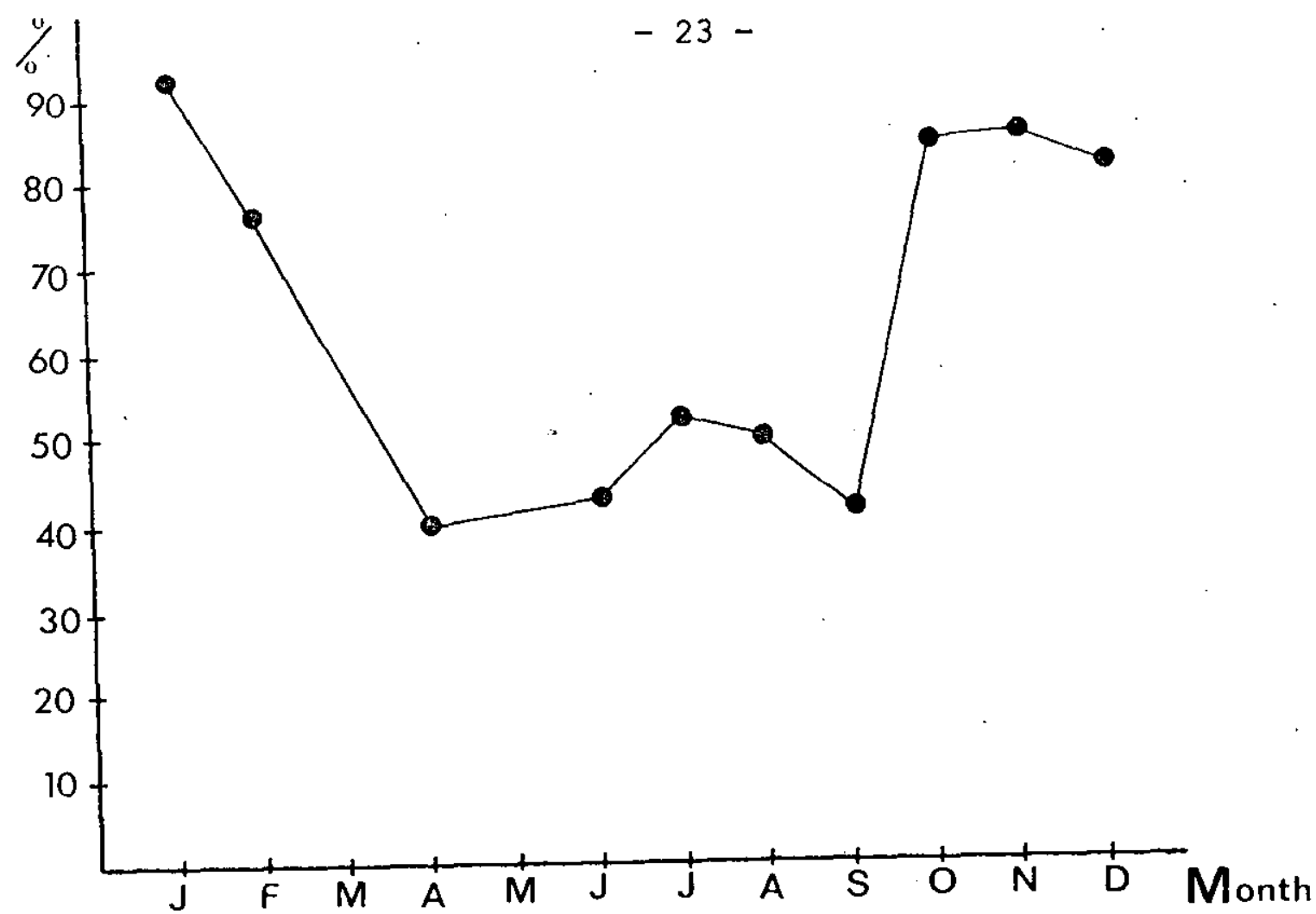

Figure 12. Monthly percentage of empty stomachs of American plaice on the Shouthern Grand Bank.

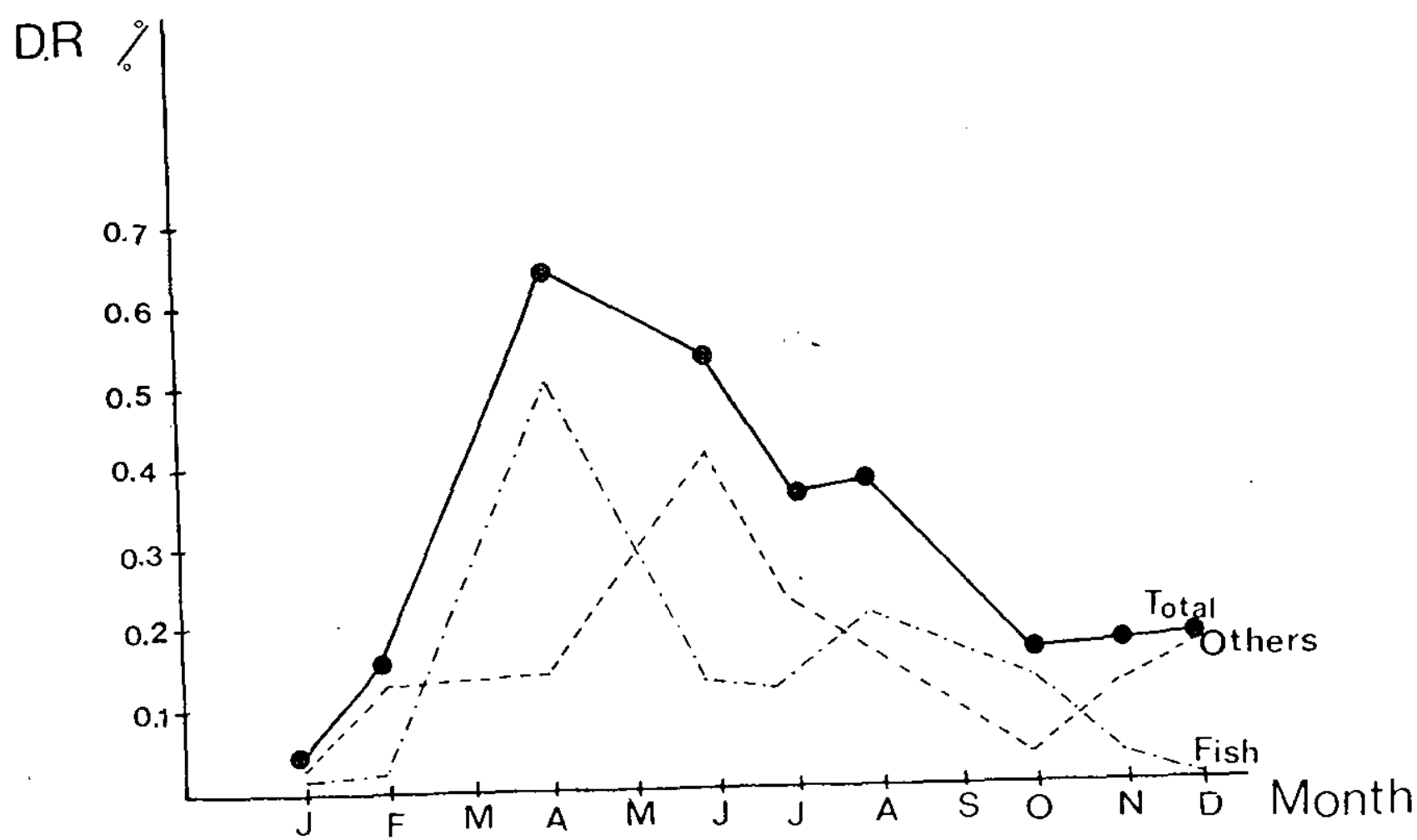

Figure 13. Monthly daily ration (D.R) of American plaice on the Southern Grand Bank. 


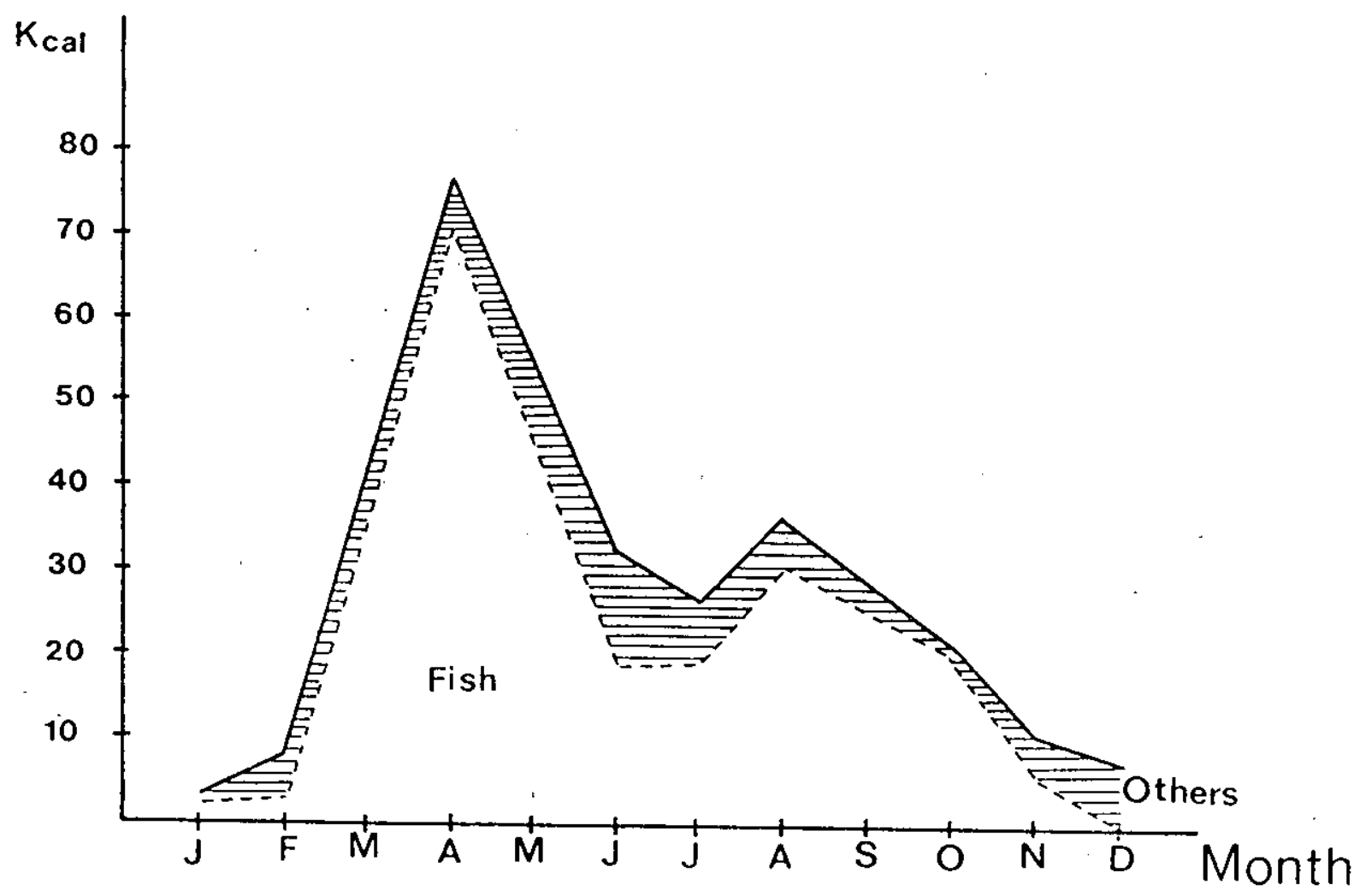

Figure 14. Monthly caloric content estimated for the annual feeding of American plaice on the Southern Grand Bank. 